\title{
Farklı dönemlerde derimi yapılan hosui asya armut (Pyrus pyrifolia) çeşidinin soğukta muhafaza performansının belirlenmesi
}

\section{Erdinç BAL}

1Namık Kemal Üniversitesi Ziraat Fakültesi Bahçe Bitkileri Bölümü, TEKİRDAĞ

Alınış tarihi: 2 Nisan 2018, Kabul tarihi: 30 Mayıs 2018

Sorumlu yazar: Erdinç BAL, e-posta:ebal@nku.edu.tr

\section{$\ddot{0} \mathbf{z}$}

$\mathrm{Bu}$ çalıșma ile farklı olgunluk aşamalarında derimi yapılan Hosui Asya Armut (Pyrus pyrifolia) çeşidi meyvelerinin $0-1{ }^{\circ} \mathrm{C}$ sicaklık ve $\% 90 \pm 5$ oransal nem koşullarında 3 ay süreyle depolanarak bazı fiziksel ve biyokimyasal kalite özelliklerinin değişimi incelenmiştir. Depolama sırasında aylık olarak, ağırlık kaybı, suda çözünebilir toplam kuru madde miktarı, titre edilebilir asit içeriği, meyve eti sertliği, askorbik asit miktarı, toplam fenolik madde miktarı, toplam antioksidan miktarı ve içsel kahverengileşme oranı gibi fiziksel ve kimyasal parametrelerde meydana gelen değişmeler belirlenmiştir. Elde edilen sonuçlara göre, farklı zamanda derimi yapılan armut meyvelerinde ağırlık kaybı bakımından farklılık önemsiz bulunmuştur. Depolama süresince meyve eti sertliği ve titre edilebilir asit içeriği azalırken, suda çözünebilir toplam kuru madde miktarı artmıștır. III. derim zamanı meyvelerinde kalite değișimleri daha belirgin bir şekilde ortaya çıkmış ve depolama süresinin sonunda en düşük askorbik asit (16.3 mg $100 \mathrm{~g}^{-1}$ ), fenolik madde (574.2 mg GAE $100 \mathrm{~g}^{-1}$ ) ve antioksidan miktarı $\left(0.955 \mu \mathrm{mol} \mathrm{g}^{-1}\right)$ bu dönemde derilen meyvelerde tespit edilmiştir. 3 aylık depolama periyodu sonunda, III. derim zamanı meyvelerinde içsel kahverengileșme oranı \%31-55 arasında gerçekleștiği için pazarlanabilir kalite özelliğini önemli oranda yitirmiştir. Tüm kalite değişimleri dikkate alındığında en iyi depolama performansı I. derim zamanına ait meyvelerden elde edilmiştir.

Anahtar kelimeler: Asya armut, depolama, derim, kalite

\section{Determination of cold storage performance of hosui asian pear (Pyrus pyrifolia) fruit harvested in different periods}

\begin{abstract}
In this study, the changes of some physical and biochemical quality characteristics of Hosui Asian Pear (Pyrus pyrifolia) variety fruits harvested at different stages of maturation were investigated at $0-1{ }^{\circ} \mathrm{C}$ and $90 \pm 5 \%$ relative humidity for 3 months. Changes in physical and chemical parameters such as weight loss, total soluble solid content, titratable acid content, flesh firmness, ascorbic acid content, total phenolic content, total antioxidant content and incidence of internal browning were determined monthly during storage. According to the results obtained, the difference between weight loss of the fruit from different harvest dates were slight. The amount of total soluble solids content increased during storage, while firmness and titratable acidity decreased. Quality changes in the third harvest time fruits appeared more prominently. At the end of the storage period, the lowest ascorbic acid (16.3 mg $100 \mathrm{~g}^{-1}$ ), phenolic content (574.2 mg GAE $100 \mathrm{~g}^{-1}$ ) and antioxidant content $\left(0.955 \mu \mathrm{mol} \mathrm{g}{ }^{-1}\right)$ were detected in the fruit from third harvest. At the end of the 3 monthstorage period, the third harvest time fruits lost marketable quality significantly due to the internal browning rate of $31-55 \%$. When all quality changes are considered, the best storage performance is obtained from the fruits of the first harvest time.
\end{abstract}

Key words: Asian pear, storage, harvest, quality 


\section{Giriş}

Ülkemiz, armutların doğal yayılma alanı ve gen merkezi içerisinde bulunduğundan hemen hemen tüm bölgelerde yetiştirilmekte ve çok sayıda çeşitten yararlanılmaktadır. Ancak ekonomik anlamda armut yetiştiriciliğinde Avrupa grubu (Pyrus communis) armut çeşitleri, Asya grubu (Pyrus pyrifolia) armut çeşitlerine göre daha çok tercih edilmektedir. Bunda en büyük etmen ise meyvelerin görünüşlerinin yuvarlağa yakın olup, armuttan çok elmaya benzemesi nedeniyle ülkemizde insanlar tarafından yeni tanınmaya başlamasıdır. Son yıllarda Asya armudu olarak bilinen Pyrus pyrifolia türü içerisinde yer alan çeşitler ülkemize getirilmiş ve bu çeşitlerle yeni armut bahçeleri tesis edilmeye başlanmıştır (Ekici ve Yıldırım, 2017). Luo and Zhang (2002), Asya armutlarının Dünya'da en fazla Çin, Japonya ve Kore'de yetiştirildiğini bildirmiştir. Bununla beraber çeşitlerin olgunlaşma tarihlerinin Temmuz sonu Eylül sonu arasında gerçekleștiğini, kabuk renklerinin yeşilden kırmızıya kadar değiștiğini, meyve ağırlıklarının 100 g ile 200 g, vitamin C içeriklerinin $15.25 \mathrm{mg} 100 \mathrm{~g}^{-1}$ ile $26 \mathrm{mg}$ $100 \mathrm{~g}^{-1}$, suda çözünebilir toplam kuru madde miktarlarının ise \%10-\%14 arasında değiștiğini belirlemişlerdir.

Pyrus pyrifolia türü içerisindeki Asya grubu armutların, görünüşleri yuvarlağa yakın olup, armuttan çok elmaya benzemektedir. Yeme olumundaki meyveler sert, gevrek ve sulu bir yapıya sahiptir. Meyvelerinin çiçek çukurlarında diğer armut türleri gibi çenek yaprak izi bulunmayıp, meyve kabuğundaki lentiseller oldukça belirgindir (Akçay ve Yücer, 2008). Depolama esnasında meyve tadını muhafaza etmek Asya armutları da dahil olmak üzere birçok meyve türü için önemlidir ve meyve depolama potansiyeli maksimum etilen üretimi seviyesiyle yakından ilişkilidir (Itai et al., 1999). Asya armutlarının bazı çeşitleri (Tsu Li, Ya Li, Chojuro, Shinsui, Kikusui, Hosui) klimakterik özellikleri gösterirken bazı çeşitleri (Nijisseiki, Kosui, Niitaka) ise klimakterik özellik göstermemektedir.

Meyvelerde derim yaklaştıkça daha belirgin olarak gözlenebilen meyvenin fiziksel ve kimyasal yapısındaki değişimler, meyve kalitesini ve derim sonrası depodaki yaşamını belirleyen önemli özelliklerdendir. Asya grubu armutların hasadına genellikle kabuk rengine ve suda çözünebilir toplam kuru madde miktarına göre karar verilmektedir. Çeşide bağlı olarak değişmekle birlikte bu meyveler $0{ }^{\circ} \mathrm{C}$ ve $\% 90$ 95 oransal nemli ortamda 1-3 ay arasında depolanabilmektedir (Mitcham and Mitchell, 2002).
Ülkemizde son yıllarda yetiştiricilere firsat sağlayan Asya armut çeşitlerine artan bir ilgi olmakla birlikte (Yıldırım ve ark., 2015), Trakya bölgesinde üreticiler Asya armut çeşitleri ile yeni tanışmaktadır. Asya grubu armutlarının depolama performansını belirlemeye yönelik yeterli çalışma yapılmamıştır. $\mathrm{Bu}$ çalışmada da farklı olgunlukta derimi yapılan Hosui armut çeşidinin $0{ }^{\circ} \mathrm{C}$ ve $\% 90-95$ oransal nemli soğuk hava deposunda 3 ay süre ile depolayarak bazı fiziksel ve biyokimyasal özelliklerindeki değişimin belirlenmesi amaçlanmıştır.

\section{Materyal ve Yöntem}

Denemede materyal olarak Kırklareli ilinde yetiştirilen Asya grubu (Pyrus pyrifolia) armut çeşitlerinden Hosui çeşidi kullanılmıştır. Hosui armut çeşidi meyveleri orta irilikte, uzun saplı, basık ve şişkin, meyve eti beyaz ve sulu bir çeşittir. Çalışmada meyveler aynı yaş ve büyüklükte ağaçlardan temin edilmiş; renk, irilik vb. özelikler açısından bir örnek ve biyolojik mekanik etkiler sonucu zararlanmamış meyveler kullanılmıştır. Hasada başlangıç Eylül ayının ikinci haftası (15 Eylül) esas alınmış, bu tarihten önceki ve sonraki dönemlerde 7 gün aralıkla 2 derim (8 Eylül ve 22 Eylül) daha yapılmıştır. Meyvelerde ayıklama işlemi yapıldıktan sonra 14'lü viyollerle plastik kasalara yerleştirilerek üç gruba (H1, H2, H3) ayrılmıştır. Meyveler $0-1^{\circ} \mathrm{C}$ sıcaklık ve $\% 90 \pm 5$ oransal nem koşullarında 3 ay süreyle depolanmıştır. Denemenin başlangıcında ve soğukta muhafaza süresince 30 günde bir alınan örneklerde bazı fiziksel ve kimyasal analizler yapılmıștır. Meyvelerdeki ağırlık kaybı başlangıç ağırlığına göre her dönem $0.01 \mathrm{~g}$ duyarlı teraziyle tartım yapılarak \% olarak hesaplanmıştır. Toplam suda çözünür kuru madde (SÇKM) miktarı meyve suyunda el tipi refraktometre kullanılarak (\%) ölçülmüştür. Titre edilebilir asit (TEA) miktarı $0.1 \mathrm{~N} \mathrm{NaOH}$ ile titre edilerek malik asit cinsinden (\%) hesaplanmıştır. Meyve eti sertliği, meyvenin ekvatoral çevresi boyunca kabuğu uzaklaştırılan üç bölgeden el penetrometresi (FT 011, Effegi) ile 11 mm'lik uç kullanarak ölçülmüştür. Elde edilen değerler kg olarak belirlenmiş, daha sonra Newton'a (N) dönüştürülmüştür. Meyve suyundaki C vitamini (Laskorbik asit) miktarı 2,6-dikloroindofenol ile titrimetrik metod (Cemeroğlu 2007) kullanılarak saptanmış ve mg $100 \mathrm{~g}^{-1}$ olarak ifade edilmiştir. Toplam fenolik madde konsantrasyonu Slinkard and Singleton (1977)'nun belirttiği gibi Folin-Ciocalteau reaktifi kullanılarak ölçülmüştür. Toplam fenolik madde içeriği mg gallik asit eşdeğeri (GAE) $100 \mathrm{~g}^{-1}$ olarak belirlenmiştir. 
Toplam antioksidan miktarı DPPH (2,2-Diphenyl-1picrylhydrazyl) yöntemi ile spektrofometrik olarak belirlenmiştir ( $\mu \mathrm{mol} \mathrm{g} \mathrm{g}^{-1}$ ) (Brand-Willams et al., 1995). İçsel kahverengileşme oranı ise 5 kişilik jüri tarafından değerlendirilmiștir (1= \%1-10, 2= \%11$30,3=\% 31-55,4=\% 56-75$ ve $5=\% 76-100$ ) (Arzani et al., 2009).

Deneme tesadüf parselleri deneme desenine göre, faktöriyel düzende, 3 tekerrürlü olarak kurulmuş ve meyve kalite analizlerinde her tekerrürde 10 adet meyve kullanılmıştır. Elde edilen sonuçlar Minitab 14 istatistik paket programinda varyans analizine tabi tutulmuştur $(\mathrm{p}<0.05)$. Sonuçlar ortalama \pm standart hata olarak belirtilmiştir.

\section{Bulgular ve Tartışma}

Ağırlık kaybı, meyve muhafazasında depolama süresini sınırlayan önemli kriterlerden biridir. Depolanan ürün depo koşullarına ve çeşit özelliklerine göre su kaybeder. Araștırmada depolama sürelerinin artmasıyla meyvelerde belirgin bir ağırlık kaybı artıșı tespit edilmiş, ancak derim dönemleri arasında önemli bir farklılık tespit edilememiştir (Şekil 1). Crisosto (2000) Asya grubu armutların su kaybına duyarlı olduğu için depolama atmosferinde yüksek nem oranını (\% 90'dan fazla) korumak gerektiği ve su kaybının \% 5-7'den daha fazla olduğunda meyvelerin yeme kalitesini önemli oranda yitirdiğini belirtmiştir. Deneme de muhafaza süresi sonunda ortalama ağırlık kaybı bu değerin altında kalarak \%4-4.6 arasında gerçekleşmiştir. III. derim dönemine ait meyvelerde depolama esnasında her zaman en yüksek ağırlık kaybı değerleri görülmüştür. Bununda meyvelerde olgunluk ilerledikçe yüksek solunum ile transpirasyon kayıplarından kaynaklandığı düşünülmektedir (Kaur and Dhillon, 2015).

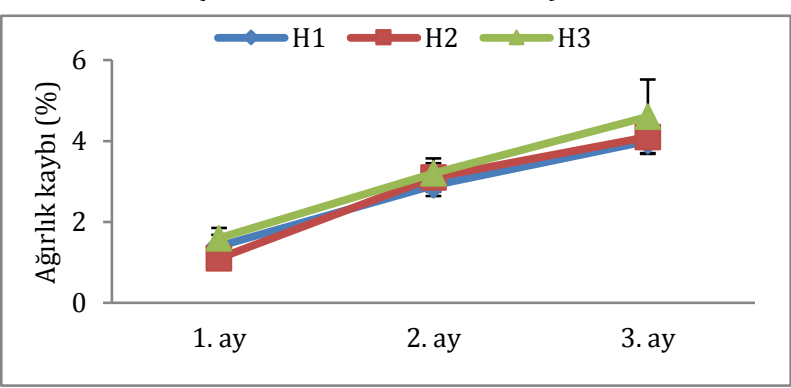

Şekil 1. Hosui Asya armut çeşidinin depolama sürecinde ağırlık kaybında saptanan değişimler

Armut meyvelerinin SÇKM içeriği, derim olgunluğu ile önemli ölçüde değişmiştir. Muhafaza sırasında armut meyvelerinde olgunluğu arttıkça derim zamanlarına bağlı olarak meyvelerdeki SÇKM miktarı artış göstermiştir (Şekil 2). Li et al. (2011), geç deri- mi yapılan armutların aşırı olgunluklarından dolayı SÇKM içeriğinin yüksek olduğunu, ancak fizyolojik bozulmalar açısından da önemli bir risk taşıdığını bildirmiştir. 3 aylık muhafaza sonunda I. derim örnekleri \%13, II. derim örnekleri \%14.3, III. derim örnekleri \%15.4 değerlerine ulaşmıştır. Büyük bir kısmını şekerlerin ve diğer karbonhidratların oluşturduğu SÇKM değerindeki bu değişimler meyve yapısındaki nişastanın şekere dönüşümünden kaynaklanmaktadır (Seymour et al., 1993). Ayrıca üründe meydana gelen su kaybı da SÇKM artışında etkili olmaktadır (Öz ve Eriş, 2009).

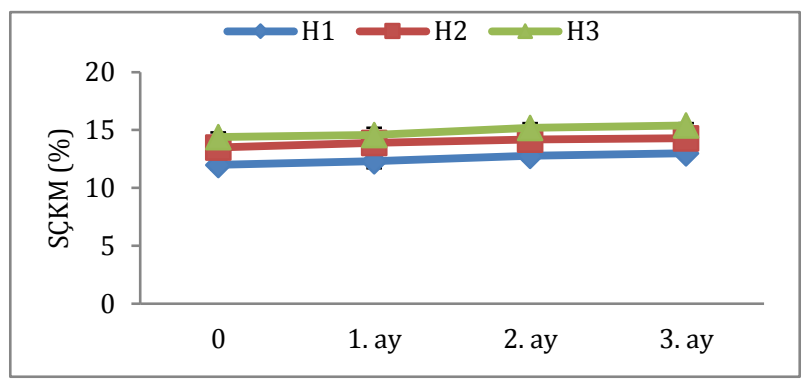

Şekil 2. Hosui Asya armut çeşidinin depolama sürecinde SÇKM miktarında saptanan değişimler

Metabolik reaksiyonlar içerisinde solunum, meyvelerin en çok enerjiye ihtiyaç duyduğu ve genellikle substrat olarak organik asitlerden faydalanılan önemli bir süreçtir (Sonkar and Ladaniya, 1999). Başlangıçta en yüksek asit değeri I. derim örneklerinde (\%0.20), en düşük asit değeri ise III. derim örneklerinde (\%0.14) bulunmuştur (Şekil 3). Araştırmada muhafaza süresince meyvelerin asitlik değerinde azalmalar belirlenmiş ve en fazla azalma ise III. derim örneklerinde (\%0.07) tespit edilmiştir. Depolama sırasındaki asitlikteki azalma, organik asitlerin şekerlere ve türevlerine dönüştürülmesi veya bunların solunumda kullanımı ile ilişkili olabilir (EccherZerbini et al., 2002). Benzer şekilde Elgar et al. (1997) daha olgun derimi yapılan armutların depolama süresince asitlik kaybının da fazla olduğunu bildirmiştir. Blaszczyk and Lysiak (2001) ve Park (2002)'da depolama esnasinda armut meyvelerinin asitliklerinde benzer değişiklikleri bildirmiştir. Depolama süresince meyve eti sertliğinde meydana gelen kayıplar meyvenin kalitesini olumsuz yönde etkilemektedir. Araştırmada soğukta muhafaza süresince tüm derim dönemlerine ait meyvelerin sertliğinde azalma meydana gelmiştir (Şekil 4). Olgunlukla birlikte giderek azalan meyve eti sertliğinin erken derimi yapılan meyvelerde hem derim zamanında hem de muhafaza sonunda daha geç derimi yapılan meyvelere göre daha yüksek kaldığı saptanmıştır. 


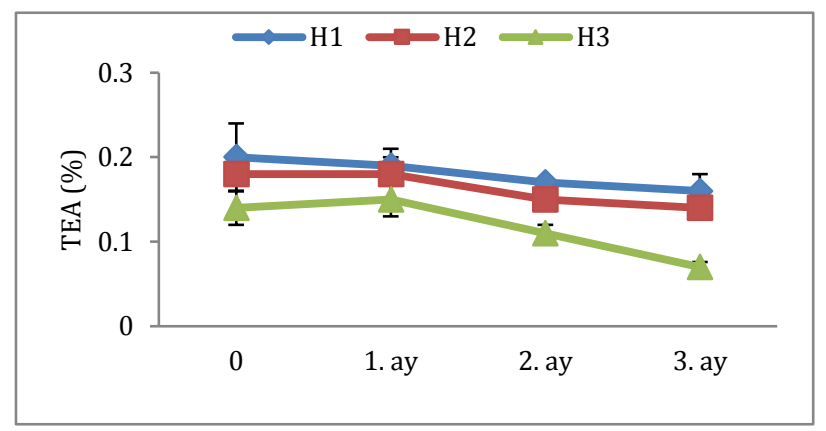

Şekil 3. Hosui Asya armut çeşidinin depolama sürecinde TEA miktarında saptanan değişimler

Muhafaza süresi sonunda tüm derim zamanlarına ait meyve eti sertliği değerleri incelendiğinde en yüksek meyve eti sertliği I. dönemde derimi yapılan meyvelerde (58.1 N) olurken, bunu II. derim (54,3 N) ve III. dönemde derimi yapılan meyveler (49.6 N) izlemiştir. Armut meyvelerinin dokularında meydana gelen yumuşama, olgunlaşma sırasında hücre duvarlarındaki değişimden ve pektinin parçalanmasından kaynaklanmaktadır. Galvis Sanchez et al. (2003) ve Drake et al. (2004), depolamada armut meyvelerinde benzer bulgular bildirmiştir. Eccher-Zerbini et al. (2002)'da depolama sürecinde daha sonraki tarihte derimi yapılan armutların daha düşük meyve eti sertliğine sahip olduğunu bildirmiştir.

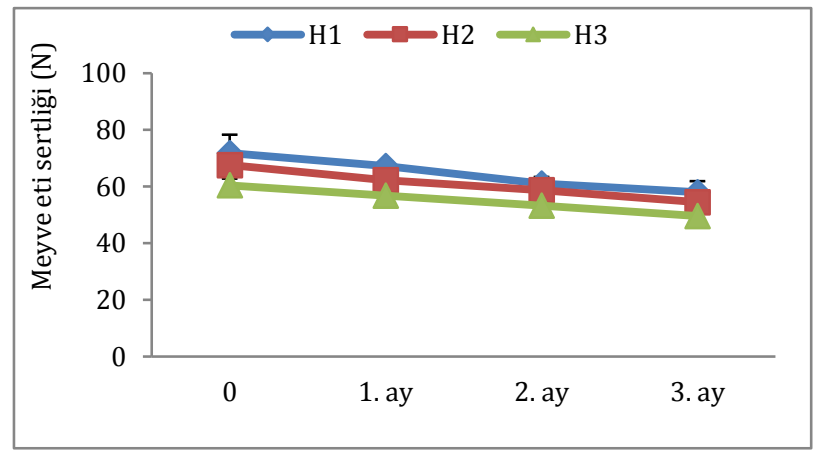

Şekil 4. Hosui Asya armut çeşidinin depolama sürecinde meyve eti sertliğinde saptanan değişimler

Askorbik asit, meyve ve sebzelerde doğrudan veya dolaylı olarak serbest radikallere karşı etkili olan önemli antioksidanlardan biridir. Ürünlerin soğukta depolanması sırasında ise genel olarak azalma eğilimi göstermektedir (Eccher-Zerbini et al., 2002). Araştırmada da derim zamanına bağlı olarak farklı oranda dalgalanmalar olmakla birlikte 3. ayda bütün derim zamanlarında başlangıç değerine göre azalmalar belirlenmiştir (Şekil 5). Denemede en yüksek askorbik asit içeriği $25.3 \mathrm{mg} 100 \mathrm{~g}^{-1}$ ile başlangıçta II. dönemde derimi yapılan meyvelerde görülürken, en düşük askorbik asit içeriği ise 3. ay'da $16.3 \mathrm{mg} 100 \mathrm{~g}$ 1 ile III. dönemde derimi yapılan meyvelerde belir- lenmiştir. Muhafaza süresi sonunda tüm derim zamanlarına ait veriler incelendiğinde en büyük askorbik asit kaybı III. dönemde derimi yapılan meyvelerde görülmüştür. Bu düşüşün sebebinin metabolizma içerisinde kullanılmalarının yanı sıra en büyük payın 3. ayda III. dönemde derimi yapılan meyvelerde içsel kahverengileşmenin artmasından kaynaklandığı düşünülmektedir. Benzer şekilde Veltman et al. (1999) ile Veltman et al. (2000)'da, belirli bir askorbik asit eşiğinin altında bulunan armutların esmerleşmeye ile içsel kahverengileşmeye meyilli olduğunu ve askorbik asitin bu bozukluğun bir göstergesi olarak kullanılabileceğini bildirmiştir.

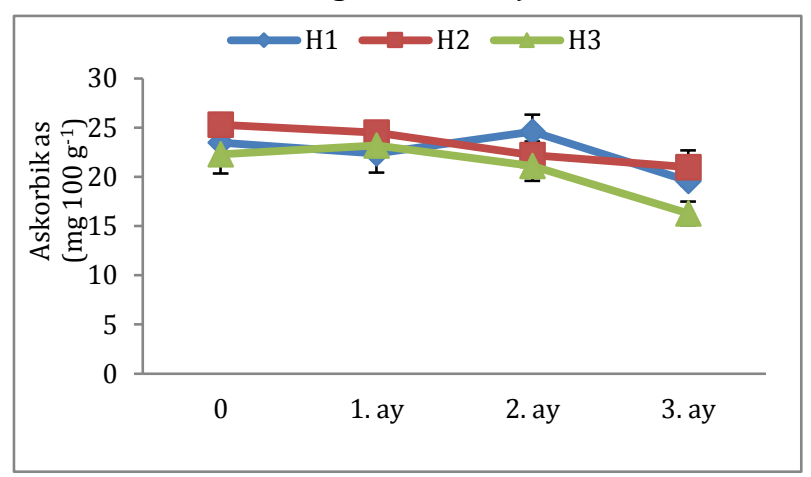

Şekil 5. Hosui Asya armut çeșidinin depolama sürecinde askorbik asit miktarında saptanan değişimler

Meyvelerde hem fenolik bileşikler hem de polifenol oksidaz enzim aktivitesi meyvelerin olgunluk seviyesinden ve depolama koşullarından etkilenmektedir. Denemede elde edilen bulgulara göre, tüm derim zamanlarına ait toplam fenolik madde miktarı 1. ayda artış göstermiș, diğer analiz dönemlerinde ise düşüş gözlemlenmiştir (Şekil 6). Armut meyvelerinde depolama süresine bağlı olarak fenolik bileşiklerde ortaya çlkan düşüşler Chen et al. (2006) ile Li et al. (2013) tarafından da belirlenmiştir. En yüksek toplam fenolik madde miktarı 1. ayda II. dönemde derimi yapılan meyvelerde (824.1 mg GAE $100 \mathrm{~g}^{-1}$ ) belirlenirken, en düşük toplam fenolik madde miktarı ise 3. ayda III. dönemde derimi yapılan meyvelerde (574.2 mg GAE $100 \mathrm{~g}^{-1}$ ) tespit edilmiştir. Elde edilen sonuçlara paralel olarak Arzani et al. (2009)'da armutlarda fenolik bileşiklerin soğukta depolama sürecinde içsel kahverengileşmenin artışına bağlı olarak azalabileceğini ve meydana gelen bu azalışın olgun meyvelerde daha fazla gerçekleştiğini bildirmiştir. Armutlar, meyve türleri içerisinde antioksidan aktivite bakımından nispeten düşük konsantrasyona sahiptir (Garcia-Alonso et al., 2004). Armutların antioksidan aktivitesi çeşide, meyve bahçesine, derim tarihine, depolama süresine ve saklama koşullarına bağlı olarak değişmektedir (Silva et al., 2008). 


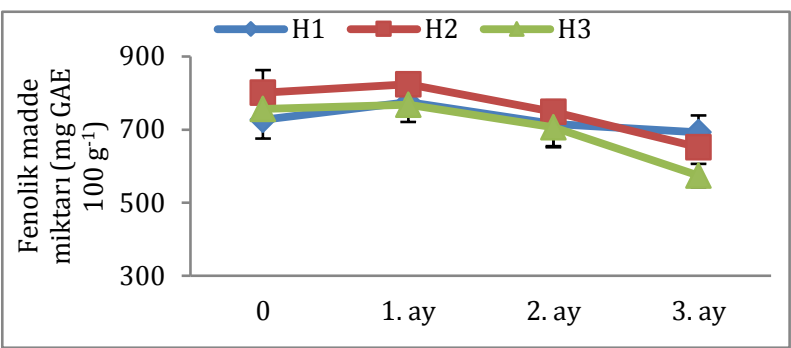

Şekil 6. Hosui Asya armut çeşidinin depolama sürecinde fenolik madde miktarında saptanan değişimler

Denemede armutlarda başlangıçta antioksidan miktarı I. dönem derimde $1.127 \mu \mathrm{mol} \mathrm{g} \mathrm{g}^{-1}$, II. dönem derimde $1.088 \mu \mathrm{mol} \mathrm{g}^{-1}$ ve III. dönem derimde 1.169 $\mu$ mol g-1 olarak belirlenmiştir (Şekil 7). Elde edilen bulgulara göre, antioksidan içeriği depolama süresine bağlı olarak artış ve azalış şeklinde değişim göstermiştir. 3. ayda en yüksek antioksidan miktarı I. derim dönemi meyvelerinde $\left(1.142 \mu \mathrm{mol} \mathrm{g}^{-1}\right)$ görülmüş, bunu II. derim dönemi $\left(1.043 \mu \mathrm{mol} \mathrm{g}^{-1}\right)$ ve III. derim dönemi meyveleri $\left(0.955 \mu \mathrm{mol} \mathrm{g}^{-1}\right)$ izlemiştir. Depolama periyodu sonunda en yüksek oranda antioksidan kaybı III. derim dönemi meyvelerinde gözlemlenmiş ve bununda yaşlanmaya bağlı olarak pazarlanabilir değerini yitirmiş olmalarından kaynaklanabileceği düşünülmektedir. Yapılan farklı çalışmalarda da muhafaza süresinin uzamasına paralel olarak armut meyvelerinin antioksidan içeriklerinde azalmaların meydana geldiği bildirilmiştir (Kou et al., 2014; Koushesh and Moradi, 2016).

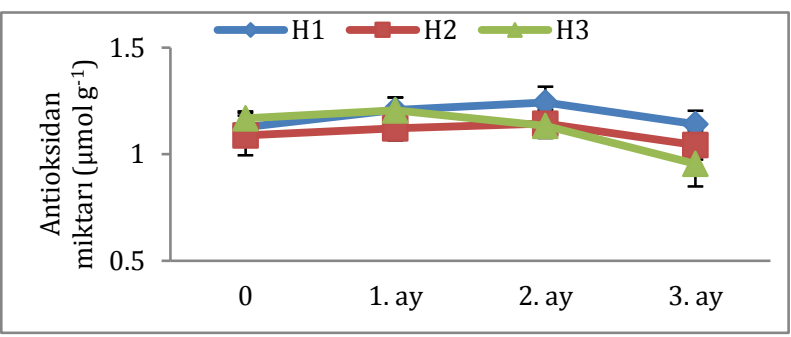

Şekil 7. Hosui Asya armut çeşidinin depolama sürecinde antioksidan miktarında saptanan değişimler

Avrupa ve Asya armut meyvelerinde genel olarak olgunluğun ilerlemesiyle esmerleşme eğilimi artmaktadır (Veltman et al., 2003; Lin et al., 2007). Denemede elde edilen bulgulara göre ilk 2 ay süresince meyvelerde herhangi bir içsel kahverengileşmeye rastlanmaz iken 3. ayda en yüksek içsel kahverengileşme oranı III. dönemde derimi yapılan meyvelerde (3.1) görülmüş ve bunu sırasıyla II. dönemde derimi yapılan meyveler (1.6) ve I. dönemde derimi yapılan meyveler (1.3) takip etmiştir (Şekil 8). Elde edilen sonuçlara göre derim tarihi ilerledikçe içsel kahverengileşme oranı artmıştır. Çalışmada mantarsal bozulmaya veya kabuk yanıklığına rastlanmamıştır.
Sonuçlara benzer șekilde, Koushesh and Moradi (2016) 8 farklı armut çeşidinde yaptıkları çalışmada, içsel kahverengileșmenin depolama süresi boyunca artığını, ancak çeşitlerin duyarlılığının farklılık gösterdiğini bildirmiștir. Crisosto et al. (1994)'da Asya grubu armutlarının erken derilmesi ile içsel kahverengileşmenin engellenebileceğini, derim zamanı geciktikçe hassasiyetin arttığını belirtmektedir.

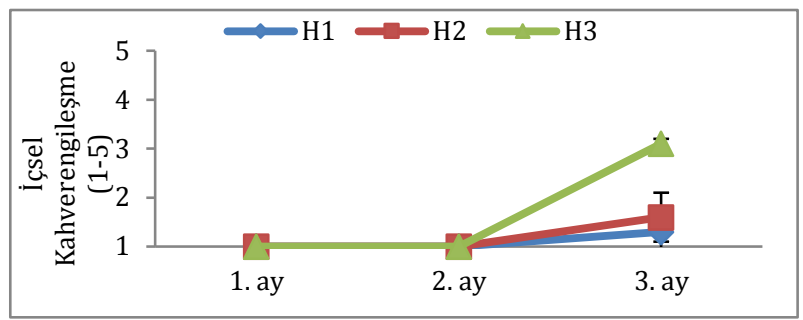

Șekil 8. Hosui Asya armut çeșidinin depolama sürecinde içsel kahverengileşme oranında saptanan değişimler

\section{Sonuç}

Yapılan fiziksel ve kimyasal analizlerin sonucu genel değerlendirme yapıldığında, Kırklareli iklim koşullarında Eylül ayının ilk haftası I. derim döneminde (SÇKM \%12, meyve eti sertliği $71.8 \mathrm{~N}$ ) derimi yapılan Hosui armut çeşidinin $0-1^{\circ} \mathrm{C}$ sicaklık ve $\% 90 \pm 5$ oransal nem içeren depoda 3 ay boyunca başarılı şekilde saklanabileceği sonucuna varılmıștır.

\section{Kaynaklar}

Akçay, M.E., Yücer, M.M., 2008. Armut. Hasat Yayınclık Limited Şti., İstanbul. $95 \mathrm{~s}$

Arzani, K., Khoshghalb, H., Malakouti, M.J., Barzegar, M., 2009. Polyphenoloxidase activity, polyphenol and ascorbic acid concentrations and internal browning in Asian pear fruit . Europ J. Hort Sci., 74(2): 61-65.

Blaszczyk, J., Lysiak, G., 2001. Storage properties of Czech pear cultivars 'Erica' and 'Dicolor'. J. Fruit Ornam. Plant Res., 9:71-76.

Brand-Williams, W., Cuvelier, M.E., Berset, C., 1995. Use of a free radical method to evaluate antioxidant activity. Lebenson Wiss Technol., 28: 25-30.

Cemeroğlu, B., 2007. Gıda analizlerinde genel yöntemler. Gıda Analizleri, Cemeroğlu, B. (ed.) , Bizim Büro Basimevi, Ankara. 317s.

Chen, J.L., Yan, S.J., Feng, Z., Xıao, L., Hu, X.S., 2006. Changes in the volatile compounds, chemical and physical properties of 'Yali' pear (Pyrus bertschneideri Reld) during storage. Food Chem., 97: 248-255.

Crisosto, C.H., Gamer, D., Crisosto, G.M., 1994. Late harvest and delayed cooling induce internal browning of Chinese pears. HortScience, 29:667-670.

Crisosto, C.H., 2000. Asian Pears. Postharvest Quality Maintenance Guidelines. http://kare.ucanr.edu/ files/123821.pdf (Erişim tarihi: 04.03.2018). 
Eccher-Zerbini, P., Grassi, M., Rizzolo, A., Pianezzola, A., De Colellis, G., Brambilla, A., 2002. Harvest maturity, mineral content and postharvest quality of 'Conference' pears. Acta Hort., 596:839-844.

Drake, S.R., Gix, R.D., 2000. Response of d'Anjou pears to controlled atmosphere storage in elevated temperature and carbon dioxide. Good Fruit Grower, 51:55-57.

Ekici, İ., Yıldırım, A.N., 2017. Asya armut (Pyrus pyrifolia) çeşitlerinin uşak koşullarında morfolojik, fenolojik, pomolojik ve bazı biyokimyasal özelliklerinin belirlenmesi. Fen Bilimleri Ens D., 21(1): 118-124.

Elgar, H.J., Watkins, C.B., Murray, S.H.F., Gunson, A., 1997. Quality of 'Buerre Bose' and 'Doyenne du Cornice' pears in relation to harvest date and storage period. Postharvest Biol Technol., 10:29-37.

Galvis-Sanchez, A.C., Fonseca, S.C., Morais, A.M.M.B., Malcata, F.X., 2003. Physicochemical and sensory evaluation of 'Rocha' pear following controlled atmosphere storage. J Food Sci., 68:318-327.

Garcia-Alonso, M., de Pascual-Teresa, S., Santos-Buelga, C., 2004. Evaluation of the antioxidant properties of fruits. Food Chemistry, 84:13-18.

Itai, A., Kawata, T., Tanabe, K., Tamura, F., Uchiyama, M., Tomomitsu, M., Shiraiwa, N., 1999. Identification of 1-aminocyclopropane-1-carboxylic acid synthase genes. Mol. Gen. Genet., 262: 42-49.

Kaur, K., Dhillon, W.S., 2015. Influence of maturity and storage period on physical and biochemical characteristics. J. Food Sci Tech., 52(8): 5352-5356.

Kou, X.H., Guo, W., Guo, R., LI, X., Xue, Z., 2014. Effects of chitosan, calcium chloride, and pullulan coating treatments on antioxidant activity in pear cv. Food Bioprocess Technol., 7(3): 671-681.

Koushesh, S.M., Moradi, S., 2016. Internal browning disorder of eight pear cultivars affected by bioactive constituentsand enzyme activity. Article in Food Chemistry 205:257-263.

Li, L., Guan, J., He, J., 2011. Effects of harvesting time on fruit quality and internal browning of 'Wonhuwang' pear. Front Agric China., 5:247-250.

Li, F., Zhang, X., Song, B., Li, J., Shang, Z., Guan, J., 2013. Combined effects of 1-MCP and MAP on the fruit quality of pear (Pyrus bretschneideri cv Laiyang) during cold storage. Sci. Hortic., 164: 544-551.

Lin, L., LI, Q.P., Wang, P.G., Cao, J.K., Jiang, W.B., 2007. Inhibition of core browning in 'Yali' pear fruit by post- harvest treatment with ascorbic acid. J. Hort. Sci. Biotech., 82: 397-402.

Luo, Z.R., Zhang, Q.L., 2002. The genetic resources and their utilization of Pyrus pyrifolia in China. Acta Hort., 587: 201-205.

Mitcham, E.J., Mitchell, F.G., 2002. Postharvest handling systems: pome fruits. Postharvest Technology of Horticultural Crops. University of California Agriculture and Natural Resources, USA, 342 pp.

Park, Y.M., 2002. Relationship between instrumental and sensory analysis of quality factors in apple and pear fruits. Korean J Hortic Sci Tech., 20:394-398.

Seymour, G.B., Taylor, J.E., Tucker, G.A., 1993. Biochemistry of fruit ripening. Chapman \& Hall, London. 454 pp.

Silva, F.J.P., Fidalgo, F., Gomes, M.H., Almeida, D.P.F., 2008. Effect of 1-Methylcyclopropene and diphenylamine on storage disorders and water-soluble antioxidants of 'Rocha' pear. Acta Hort., 800:993.

Slinkard, K., Singleton, V.L., 1977. Total phenol analysis: automation and comparison with manual methods. American J of Enology Viticulture, 28(1): 49-55.

Sonkar, R.K., Ladaniya, M.S., 1999. Individual film wrapping of Nagpur mandarin with heat stretching film. J Food Sci Tech., 36:273-76.

Öz, A.T., Eriş, A., 2009. Kontrollü atmosfer (KA) ve normal atmosfer (NA) koşullarında depolamanın farklı zamanlarda derilen "Hayward" kivi çeşidinin kalite değişimine etkisi. Gıda, 34(2):83-89.

Veltman, R.H., Sanders, M.G., Persijn, S.T., Peppelenbos, H.W., Oosterhaven, J., 1999. Decreased ascorbic acid levels and brown core development in pears (Pyrus communis). Physiol. Plant., 107: 39-45.

Veltman, R.H., Kho, R.M., Schaik, A.C.R., Sanders, M.G., Oosterhaven, J., 2000. Ascorbic acid and tissue browning in pears under controlled atmosphere conditions. Postharvest Biol. Technol., 19: 129-137.

Veltman, R., Lentherıc, L., Van Der Plas, H., Peppelenbos, W., 2003. Internal browning in pear fruit (Pyrus communis L. cv 'Conference') may be a result of a limited availability of energy and antioxidants. Postharvest Biol Technol., 28: 295-302.

Yıldırım, F., Ekici, İ., Yıldırım, A.N., Şan, B., Kelebek, C., Çoruk, T., 2015. 'Atago' ve 'Kosui' Asya armut çeşitlerinde elle seyreltme uygulamalarının meyve kaliteleri üzerine etkileri. Bahçe, 45(1): 1212-1215. 